\title{
METODE MITIGASI LONGSORLAHAN DI KECAMATAN GUMELAR KABUPATEN BANYUMAS PROVINSI JAWA TENGAH
}

\author{
Oleh: \\ Suwarno dan Sutomo \\ Pendidikan Geografi FKIP UMP
}

\begin{abstract}
ABSTRAK
Chis research aims to find formulating to mitigation of dangser of landslide, by observe on the classes of landslise dangser, the risk of landslide and the landslide disaster.

The method used in the research is survey with two kinds of variables, the dependent variable includes the classes of dangser and the classes risk for the landslide, and the independent variable is the effart of mitigation. The classes of dangser and risk. for the landslide are obfained from the secondary data, white the efforts of mitigation for the landslide are determined in accordance with the classes of landslide danser and risk. landslide by considery the supporting factors.

The result of the research shows that the field studied is the area with high risk of landslide. The dominant factors for the risk are the type of litology, and the weatering. The classes of landslide risk ranges from the low to the bigh. Hence, the efforts of mitigation should be tayseted first to those areas with the bigh risk of landslide. The efforts of mitigation to put into practive should consider. The dominant factors in the area, its can be underfaken by desighing a priovity, based on its terms covering shout ferm, medium term and long term.
\end{abstract}

Keywords: Risk, dangser and mitigation

\section{PENDAHULUAN}

Ditinjau dari faktor penyebabnya, bencana dapat dibagi dalam empat jenis, yaitu bencana alam, bencana karena ulah manusia, bencana akibat interaksi manusia dan alam, serta wabah penyakit. Jenis-jenis bencana alam meliputi gunung meletus, gempa bumi, tanah longsor, tsunami, angin ribut, banjir lahar, gas beracun, dan kekeringan. Jenis-jenis bencana karena ulah manusia meliputi kebakaran, pergolakan manusia, perang, dan pencemaran. Jenis bencana akibat interaksi alam dan manusia antara lain banjir. Jenis-jenis bencana akibat wabah penyakit meliputi serangan hama wereng atau belalang, endemic malaria, dan lain sebagainya ( Andjasmara, 1994 dalam Mardiatna, 2001 ).

Sutikno (1985), membedakan dampak bencana longsorlahan terhadap lingkungan fisik atas dasar tempat kejadiannya menjadi tiga yaitu:

1) daerah asal terjadinya longsorlahan, terjadi pemotongan lereng, pengurangan material, kerusakan lahan daerah sekitar yang berakibat erosi menjadi lebih aktif;

2) daerah yang dilalui terjadi kerusakan lahan pertanian, permukiman, vegetasi, dan bangunan fisik dan topografi 
bergelombang yang juga mempercepat erosi;

3) daerah yang tertimbun mempunyai dampak yaitu: vegetasi, permukiman tertimbun dan tata air keadaannya sangat labil sehingga proses berikutnya masih sering terjadi.

Kecamatan Gumelar merupakan daerah yang labil, berarti sangat sensitive terhadap peristiwa alam terutama longsorlahan. Berdasarkan penelitian Suwarno 2004 dan 2005 diperoleh hasil daerah tersebut mempunyai kelas bahaya rendah sampai sangat tinggi dan mempunyai kelas risiko longsorlahan antara rendah hingga tinggi dan pada daerah tersebut sering terjadi longsorlahan. Oleh Karena itu perlu tindakan mitigasi bahaya longsorlahan tersebut berdasarkan pertimbangan kelas bahaya dan kelas risiko longsorlahan dan bila terjadi longsoran dapat meminimalkan kerugian yang timbul akibat kejadian dan mengantisipasi tindakan yang tepat untuk pencegahannya.

Pada setiap satuan medan mempunyai karakteristik yang berbeda tergantung dari parameter medannya. Oleh karena itu kejadian longsorlahan pada setiap satuan medan berbeda. Kejadian longsorlahan dipengaruhi oleh karakteristik medan, sedang risiko dipengaruhi oleh faktor kerugian jiwa maupun harta benda. Akibat dari kejadian longsorlahan tersebut adalah rusaknya permukiman, prasarana fisik dan sosial ekonomi, dan aktivitas ekonomi pada sawah, ladang dan kebun. Maka perlu dilakukan tindakan-tindakan khusus untuk mencegah atau mengurangi kejadian longsorlahan dan meminimalkan risiko yang diakibatkan oleh kejadian longsorlahan tersebut atau mitigasi bahaya longsorlahan.
Thornbury (1954), menjelaskan proses geomorfologi adalah semua perubahan baik secara fisik maupun kimia yang mampu merubah muka bumi. Berdasarkan tenaga geomorfologinya, maka proses tersebut dibedakan menjadi proses eksogen dan proses endogen. Proses endogen meliputi volkanisme dan diastrofisme, sedang proses eksogen terdiri dari degradasi dan agradasi. Degradasi terdiri dari pelarutan, dan gerak massa batuan, sedang gerak massa batuan terdiri dari 2 tipe yaitu tipe aliran lambat dan tipe aliran cepat. Tipe aliran lambat dibedakan menjadi soil creep, talus creep, rock creep, rock glacier creep dan soil fluction, sedangkan tipe aliran cepat dapat dibedakan menjadi earthflow, mudflow, debris avalanche, landslide, slump, debris slide, debris fall, rock slide, rock fall, dan subsidence. Dalam penelitian ini yang menjadi kajian adalah landslide atau longsorlahan yang terdapat di Sub Daerah Aliran Sungai Tajum.

Longsorlahan dapat menyebabkan terjadinya bencana alam, dampak yang ditimbulkan oleh bencana alam ini sangat bervariasi tergantung dari intensitas bencana serta kondisi sosial ekonomi daerah yang terkena bencana. Secara umum dampak bencana ini dapat dikelompokkan menjadi 2 yaitu dampak terhadap lingkungan fisik dan dampak terhadap lingkungan sosial-ekonomi (Sutikno, 1985). Longsorlahan yang merupakan proses alam dapat menyebabkan timbulnya bencana termasuk dalam proses geomorfik yang bekerja di permukan bumi yang cenderung mengubah konfigurasi muka bumi.

Bahaya adalah suatu peristiwa yang mengancam atau probabilitas kejadian dari fenomena yang secara potensial merusak dalam periode waktu dan tempat yang tertentu, sedang risiko adalah mengasumsikan 
kerugian atau kehilangan (jiwa, korban lukaluka, harta benda, aktifitas ekonomi) yang disebabkan bahaya khusus dalam suatu wilayah selama periode waktu tertentu (Melching, 1999).

Mitigasi adalah suatu tindakan sebelum bencana terjadi untuk mengurangi seminimal mungkin kerugian harta benda atau korban jiwa. Dalam mitigasi diupayakan agar efek fisik, sosial, dan ekonomi dari bencana alam dapat terkelola dengan baik, sehingga masih memberikan kontribusi terhadap pembangunan jangka panjang (Sutikno, 1994). Mustow (1994, dalam Sutikno, 1994) menyatakan bahwa mitigasi merupakan bagian dalam siklus penanganan bencana. Aktifitas dalam penangannan bencana meliputi: mitigasi, persiapan, pertolongan/bantuan dan respon, rehabilitasi, dan rekontruksi. Walaupun dalam kenyataannya pemberian bantuan pasca bencana selama ini merupakan kegiatan yang lebih penting, namun sudah saatnya untuk disosialisasikan kepada publik bahwa mitigasi lebih baik daripada pegobatan. Pengalokasikan waktu dan sumberdaya untuk meminimalkan efek bencana alam akan lebih baik daripada menghadapi kenyataan akibat bencana.

Nitihardjo (1992) dalam tulisannya yang berjudul The Susceptibility to Landslide in Enrekang Area, South Sulawesi, Indonesia menjelaskan bahwa mitigasi dampak bahaya longsor sebaiknya dilakukan dengan menentukan area potensial mengalami pergeseran (sliding) dan menyajikan hasilnya dalam bentuk peta. Metode yang digunakan untuk menentukan kerentanan didasarkan pada faktor-faktor dan parameter-parameter geologi dan khususnya litologi, inklinasi lereng, bukti-bukti adanya longsoran, dan faktor-faktor lain seperti hujan, penggunaan lahan, dan kegempaan (sesismicity). Berdasarkan parameter-parameter dan faktor keamanan tanah, daerah penelitian dapat dibagi menjadi empat mintakat rentan longsor: very low landslide susceptible zone, low landslide susceptible zone, moderate landslide susceptible rone, dan bigh landslide susceptible zone. Kriteria faktor keamanan yang digunakan mendasarkan pada kriteria Ward, yaitu: Fs <1,2 ; Fs 1,2 s.d. $<1,7$; Fs 1,7 s.d. $<2$; dan Fs $>2$.

Hasil penelitian yang dilakukan oleh Dinas Pengairan Pertambangan dan Energi Kabupaten Banyumas bekerja sama dengan Lembaga Penelitian dan Perberdayaan Masyarakat ITB (2003), metode yang digunakan survei lapangan dengan variabel kerentanan tanah dan lereng, maka diperoleh hasil bahwa di wilayah Kecamatan Lumbir dan Pekuncen menunjukkan bahwa daerah tersebut rawan terhadap bencana gerakan tanah. Di Kecamatan lumbir dari hasil penelitian tersebut zone yang kerentanan gerakan tanah sangat rendah 3,04\%, zone kerentan gerakan tanah rendah $11,99 \%$, zone kerentanan gerakan tanah menengah 35,24\%, dan zone kerentanan gerakan tanah tinggi 42,27\% dari seluruh daerah pemetaan, sedang di Kecamatan Pekuncen terdapat empat zone daerah rawan gerakan tanah juga yaitu zone kerentanan gerakan tanah sangat rendah $11,25 \%$, zone kerentanan gerakan tanah rendah 39,47\%, zone kerentanan gerakan tanah menengah $44,46 \%$ dan zone kerentanan gerakan tanah tinggi4,82\% dari seluruh daerah pemetaan.

Penelitian ini bertujuan untuk mengetahui usaha-usaha untuk mitigasi bahaya longsorlahan dengan memperhatikan kelas bahaya longsor, resiko longsor dan bencana longsor. 
Penelitian ini diharapkan dapat menambah khasanah perkembangan ilmu pengetahuan khususnya pada bidang geomorfologi, membantu dalam perencanan tata guna lahan di Kabupaten Banyumas dan khususnya di Kecamatan Gumelar.

\section{METODE PENELITIAN}

\section{Bahan}

Bahan Penelitian meliputi: Peta Kelas Bahaya Longsorlahan dan Peta Kelas Risiko Longsorlahan Kecamatan Gumelar.

\section{Tahap Penelitian}

Penelitian dilakukan melalui tahaptahap sebagai berikut yaitu tahap pra lapangan, tahap lapangan, dan tahap pasca lapangan. Tahap pra lapangan meliputi interpretasi foto udara pankromatik hitam putih dan peta-peta bahan yaitu peta bahaya dan peta risiko longsorlahan daerah penelitian.

Pada tahap lapangan dilakukan pengamatan dan pengukuran faktor-faktor yang dominan dan spesifik yang berpengaruh terhadap kelas bahaya dan kelas risiko longsorlahan atau faktor pemberatnya sebagai pertimbangan dalam penentuan mitigasi.

Pada tahap pasca lapangan dilakukan analisis faktor-faktor pemberat pada masing-masing kelas bahaya dan risiko longsorlahan, ini dimaksudkan untuk mengetahui akan dilakukan tindakan apa dalam mitigasi apabila terjadi bahaya longor tersebut sehingga korban dan kerugian harta benda dapat diminimalisasi sebesar mungkin.

\section{Perolehan Data}

Data yang dikumpulkan berupa data sekunder yang berpengaruh terhadap bahaya longsorlahan dan risiko longsorlahan yang bersumber dari hasil penelitian ter- dahulu dan dari intansi terkait. Data tersebut meliputi karakteristik medan yang meliputi data lereng, tanah, batuan, proses geomorfologi, airtanah, dan kondisi lahan serta kejadian longsorlahan sebelumnya, data iklim dan data statistik daerah penelitian, yaitu data kependudukan dan sosial ekonomi yang berupa data jumlah penduduk dan data aset harta benda berupa sawah, ladang, kebun, ternak, dan rumah beserta isinya dan data sekunder lainnya berupa data tematik yang berupa peta-peta tematik yang terkait dengan penelitian.

\section{Variabel Penelitian}

Dalam penelitian ini terdapat tiga variabel yaitu kelas bahaya longsorlahan dan risiko longsorlahan sebagai variabel bebas, dan metode mitigasi longsorlahan sebagai variabel terokat.

\section{Analisa Data}

Analisis terhadap data yang diperoleh dilakukan dengan melakukan over lay masing-masing variable, variabel kelas bahaya longsorlahan diperoleh dengan cara pengharkatan masing-masing parameter medan dari pengharkatan tersebut dicari kelas bahayanya, dan variabel risiko longsorlahan ditentukan dengan menghitung kerugian bila terjadi longsorlahan dengan kelas bahaya longsorlahan. Untuk analisa dua variable tersebut menggunakan System Informasi Geografi, hasil dari analisis ini digunakan untuk menentukan mitigasi bahaya longsorlahan yang sesuai pada masing-masing satuan medan.

\section{HASIL DAN PEMBAHASAN}

\section{Letak}

Daerah penelitian terletak di Kecamatan Gumelar Kabupaten Banyumas Provinsi Jawa Tengah, dan secara 
astronomis terletak pada $108^{\circ} 56^{\prime} 44^{\prime \prime}$ $109^{\circ} 02^{\prime} 34^{\prime \prime}$ BT dan $07^{\circ} 19^{\prime} 35^{\prime \prime}$ - $07^{\circ} 28^{\prime}$ 00 " LS.

\section{Geologi}

Secara geologi daerah penelitian terletak pada jalur geologi jawa bagian tengah yang merupakan jalur basin tengah yang ditumbuhi oleh jalur volkan (Pannekock, 1949), sedang menurut Bemmelen, (1949) daerah penelitian termasuk pada Propinsi Geologi Jawa Tengah pada zone jalur pegunungan Serayu bagian utara.

Struktur geologi yang terdapat pada daerah penelitian adalah struktur berlapis sederhana sampai dengan miring dengan dip perlapisan lebih dari $45^{\circ}$ dan arah perlapisannya ke berbagai arah. Batuan yang terdapat di daerah penelitian adalah batugamping, batu tuffa, batupasir, batu napal, batu sedimen volkanik dan batulempung. Batugamping terdapat di sebagian besar daerah penelitian yang sebarannya pada bagian timur yang berbatasan dengan Kecamatan Ajibarang yang memanjang ke arah barat mulai dari Paningkaban sampai dengan Mangjinklak. Batutuffa terdapat di daerah Karangkemujing sampai dengan daerah Lumbir, dan daerah Ratadawa dan di daerah Cilangkap terdapat batutuffa pasiran. Batupasir terdapat di daerah Munggangbawang, Babakan dan Tlaga. Batuan sedimen volkanik terdapat di daerah Dawuhan dan Renggong, sedang batuan lempung terdapat menyebar di daerah penelitian ini dapat dilihat pada dasar Sungai Tajum yang berupa batulempung.

\section{Geomorfologi}

Kondisi geomorfologi daerah penelitian secara umum adalah perbukitan dan lembah antar perbukitan. Di antara perbukitan tersebut terbentuk sistem aliran dan sungai terbesar yang terdapat di daerah penelitian adalah Sungai Tajum. Dasar dari Sungai Tajum adalah batuan lempung, yang mana ini menunjukkan bahwa daerah tersebut merupakan daerah pengendapan laut dan mengalami pengangkatan. Berdasarkan genesanya daerah penelitian dapat dibedakan menjadi beberapa satuan bentuklahan yaitu: perbukitan denudasional berbatuan gamping tertoreh kuat, perbukitan denudasional berbatuan tuffa tertoreh sedang, perbukitan denudasional berbatuan pasir tertoreh kuat, perbukitan denudasional berbatuan sedimen volkanik tertoreh sedang, dan lembah antar perbukitan.

\section{Tanah}

Daerah penelitian terdapat berbagai macam jenis tanah antara lain litosol yang mempunyai agihan paling luas, tanah mediteran, tanah latosol, dan tanah aluvial. Tanah litosol adalah kategori tanah muda dengan ciri solum tanah antara $10 \mathrm{~cm}$. sampai dengan $25 \mathrm{~cm}$. saja bahkan hanya terlihat batuan dasarnya, horison tanah yang terbentuk adalah horison Ap yaitu horison $\mathrm{C}$ yang diolah untuk pertanian. Kesuburan tananya rendah, produksinya rendah, tekturnya didomonasi oleh pasir. Tanah mediteran dan latosol mempunyai ciri-ciri yang hampir mirip hanya terdapat perbedaan pada strukturnya pada horison B, solum tebal, kesuburan sedang hingga tinggi. Tanah aluvial adalah tanah yang terbentuk dari hasil penendapan oleh aliran air baik itu air sungai maupun aliran permukaan. Tanah aluvial mempunyai ciri tidak terbentuk horison tanah, lapisan tanahnya tebal, kesuburan sedang hingga tinggi, tektur bervariasi dari pasir hingga lempung.

\section{Penggunaan Lahan}

Penggunaan lahan di daerah penelitian bervariasi yaitu untuk permukiman, 
sawah tadah hujan, tegalan, kebun campuran dan hutan. Tegalan dan hutan menempati luas yang paling banyak, sedang untuk permukiman dan sawah menempati ruang yang terkecil atau sempit.

\section{Parameter medan}

Parameter medan yang akan diuraikan pada bagian ini adalah meliputi parameter yang digunakan untuk pengklasifikasikan kelas bahaya longsorlahan adalah sebagai berikut:

\section{Lereng}

Faktor lereng yang dimaksud pada penelitian adalah kemiringan lereng yang dinyatakan dengan persentase. Besarnya lereng bervariasi dari klas lereng II hingga klas lereng V. Kelas kemiringan lereng terendah terdapat pada satuan bentuklahan lembah antar perbukitan, kelas kemiringan terbesar yaitu kelas $\mathrm{V}$ terdapat pada satuan medan dari satuan bentuklahan perbukitan denudasional berbatuan gamping dan sedimen.

\section{Tanah}

Faktor tanah yang dimaksud dalam penelitian ini adalah tekstur tanah, permeabilitas tanah dan ketebalan tanah. Tekstur tanah di daerah penelitian berdasarkan analisa laboratorium adalah geluh, geluh debuan, lempung, geluh lempungan, dan geluh lempung debuan. Permeabilitas tanah dari analisa laboratorium diperoleh kelas permeabilitas sedang hingga sangat lambat. Solum tanah berkisar dari $10 \mathrm{~cm}$ hingga lebih dari $150 \mathrm{~cm}$.

\section{Kedalaman Pelapukan Batuan}

Kedalaman pelapukan batuan dapat diamati dari singkapan batuan yang ada dan untuk menentukan batuan itu sudah lapuk atau belum yaitu dengan memukul-mukul batuan tersebut dengan menggunakan palu geologi maka dapat diamati kondisi batuan itu sudah lapuk atau belum. Dengan demikian maka kedalaman pelapukan dapat diukur dari permukaan tanah sampai dengan perlapisan batuan yang lapuk tersebut. Kedalaman pelapukan batuan berkisar dari $25 \mathrm{~cm}$ hingga lebih dari $120 \mathrm{~cm}$.

\section{Dinding Terjal}

Merupakan fenomena alam yang terjadi oleh peristiwa alam maupun buatan manusia. Untuk menentukan banyaknya dinding terjal pada tiap-tiap satuan medan yaitu dengan cara mengamati pada tiap satuan medan baik itu melalui interpretasi foto udara, peta topografi dan pengamatan lapangan, sedang penentuan banyak sedikitnya dinding terjal tersebut berdasarkan prosentase dari luasan satuan medan.

\section{Torehan}

Torehan merupakan fenomena fisik yang terdapat di permukaan medan yang merupakan hasil sisa dari proses erosi yang berupa alur-alur atau parit-parit. Untuk menentukan ada tidaknya torehan pada setiap satuan medan adalah dengan melakukan interpretasi foto udara pankromatik hitam putih skala $1: 50.000$, dan melakukan pengamatan pada permukaan medan dengan panjang 100 meter pada daerah sampel bila pada foto udara tidak jelas kenampakannya, maka dari permukaan 100 $m$ itu diamati ada tidaknya torehan dan bila ada jumlah torehannya dihitung banyaknya. Pada daerah penelitian kerapatan atau banyaknya torehan bervariasi dari tanpa sampai tinggi.

\section{Penggunaan lahan}

Di daerah penelitian penggunaan lahannya terdapat beberapa macam. Hasil dari interpretasi foto udara pankromatik 
hitam putih skala 1 : 50.000, dan pengamatan lapangan, maka penggunaan lahannya adalah sawah, permukiman, kebun campuran, hutan, dan tegalan.

\section{Struktur perlapisan batuan}

Struktur perlapisan batuan ditentukan berdasarkan pengamatan di lapangan melalui singkapan batuan yang ada pada setiap satuan medan, untuk satuan medan yang tidak terdapat singkapan batuan maka struktur perlapisan batuan dianggap horisontal, tegak dan miring dan untuk klasifikasinya didasarkan pada kemiringan lereng dan topografinya. Sebagian besar pada daerah penelitian struktur perlapisan batuannya miring dengan kemiringan antara $6^{0}$ sampai dengan $23^{\circ}$

\section{Kelas Bahaya dan Risiko Longsorlahan}

Dalam menganalisis atau menentukan kelas bahaya dan kelas risiko longsorlahan dengan mengguakan metode pengharkatan masing-masing parameter medan pada setiap satuan medan. Satuan medan di daerah penelitian disusun berdasarkan satuan bentuklahan dan lereng, maka satuan medan yang terdapat di daerah penelitian adalah : perbukitan denudasional berbatuan gamping tertoreh kuat dengan lereng kelas III, IV, dan V, perbukitan denudasional berbatuan tuffa tertoreh sedang dengan kelas lereng III dan IV, perbukitan denudasional berbatuan pasir tertoreh kuat dengan kelas lereng III, IV,dan V, perbukitan denudasional berbatuan sedimen volkanik tertoreh sedang dengan kelas lereng III dan IV, dan lembah antar perbukitan dengan kelas lereng II. Tabel berikut menyajikan Kelas bahaya dan kelas risiko longsorlahan di daerah penelitian

\section{Metode Mitigasi}

Untuk mitigasi longsorlahan harus memperhatikan beberapa hal yaitu kelas bahaya dan kelas risiko longsorlahannya, akan tetapi yang paling utama yaitu melihat kelas risiko terlebih dahulu yaitu mendahulukan pada wilayah yang berisiko tinggi lebih diutamakan dalam mitigasi, untuk wilayah penelitihan yang menjadi prioritas utama mitigasi adalah pada satuan medan Perbukitan denudasional berbatuan pasir lereng 3 di daerah Paningkaban yang mempunyai kelas risiko tinggi dan disamping itu kelas bahayanya juga tinggi. Oleh karena itu usaha mitigasi yang bisa dilakukan antara lain sebagai berikut: Crozier (2004, 340), memberikan beberapa metode untuk mitigasi longsorlahan sebagaiberikut:

1. metode fisik meliputi: 1) Pembuatan kaki penyangga lereng, 2) Penguatan lereng dengan patok kayu, jangkar, penjepit, pancangan, menutup celah dan retakan, 3) Penguatan secara kimia pada tanah, 4) Mengalihkan runtuhan: penggalian, dirajut, dam penahan runtuhan, 5) Bio teknik.

2. metode hidrologi meliputi: 1) Mengalihkan aliran permukaan ke tempat lain, 2) Penutup tanah yang inpermeabel, 3) Pengatusan, 4) Pengeringan runtuhan cair, 5) Pengatusan atau pengurangan tubuh air yang menyumbangkan tenaga besar.

3. Penataan lokasi meliputi: 1) Pemotongan kayu dan memperkecil kekuatan kejadian runtuhan, 2) Merubah kontur permukaan dari (penyebaran air) atau menutup saluran dan celah-celah, 3) Pemotongan material yang rentan, 4) Bio teknik.

4. Sistem peringatan meliputi: 1) Survei berkala: memonitor yang terus menerus, 2) Sistem dasar tanda bahaya dengan menggerakkan alat / akumulasi curah hujan, getaran, sistem tanda bahaya aktivitas gerakan lereng. 
Tabel : Kelas Bahaya dan Risiko Longsorlahan di Daerah Penelitian.

\begin{tabular}{|l|l|l|c|c|c|c|}
\hline No & \multicolumn{1}{|c|}{ Satuan medan } & Kelas bahaya & $\begin{array}{c}\text { Harkat } \\
\text { kelas } \\
\text { bahaya }\end{array}$ & $\begin{array}{c}\text { Harkat } \\
\text { kerugian }\end{array}$ & $\begin{array}{c}\text { Total } \\
\text { harkat }\end{array}$ & $\begin{array}{c}\text { Kelas } \\
\text { risiko }\end{array}$ \\
\hline 1 & $\begin{array}{l}\text { Perbukitan denudasional ber- } \\
\text { batuan tuffa lereng 3 }\end{array}$ & Bahaya tinggi & 4 & 3 & 7 & Sedang \\
\hline 2 & $\begin{array}{l}\text { Perbukitan denudasional ber- } \\
\text { batuan tuffa lereng 4 }\end{array}$ & Bahaya sedang & 3 & 2 & 5 & Rendah \\
\hline 3 & $\begin{array}{l}\text { Perbukitan denudasional ber- } \\
\text { batuan gamping lereng 3 }\end{array}$ & Bahaya tinggi & 4 & 3 & 7 & Sedang \\
\hline 4 & $\begin{array}{l}\text { Perbukitan denudasional ber- } \\
\text { batuan gamping lereng 4 }\end{array}$ & Bahaya tinggi & 4 & 3 & 7 & Sedang \\
\hline 5 & $\begin{array}{l}\text { Perbukitan denudasional ber- } \\
\text { batuan gamping lereng 5 }\end{array}$ & $\begin{array}{l}\text { Bahaya sangat } \\
\text { tinggi }\end{array}$ & 5 & 1 & 6 & Sedang \\
\hline 6 & $\begin{array}{l}\text { Perbukitan denudasional ber- } \\
\text { batuan pasir lereng 3 }\end{array}$ & Bahaya tinggi & 4 & 4 & 8 & Tinggi \\
\hline 7 & $\begin{array}{l}\text { Perbukitan denudasional ber- } \\
\text { batuan pasir lereng 4 }\end{array}$ & Bahaya sedang & 3 & 2 & 5 & Rendah \\
\hline 8 & $\begin{array}{l}\text { Perbukitan denudasional ber- } \\
\text { batuan pasir lereng 5 }\end{array}$ & Bahaya tinggi & 4 & 1 & 5 & Rendah \\
\hline 9 & $\begin{array}{l}\text { Perbukitan denudasional ber- } \\
\text { batuan sediment volkanik le- } \\
\text { reng 3 }\end{array}$ & Bahaya sedang & 3 & 4 & 7 & Sedang \\
\hline 10 & $\begin{array}{l}\text { Perbukitan denudasional ber- } \\
\text { batuan sediment volkanik le- } \\
\text { reng 4 }\end{array}$ & Bahaya tinggi & 4 & 3 & 7 & Sedang \\
\hline 11 & $\begin{array}{l}\text { Lembah antar perbukitan le- } \\
\text { reng 2 }\end{array}$ & Bahaya rendah & 2 & 5 & 7 & Sedang \\
\hline
\end{tabular}

Sumber: Suwarno,2004 dan 2005.

5. Peraturan meliputi: 1) Peraturan membangun, 2) Standar fundasi dan pengatusan, 3) Peraturan keselamatan hidup, 4) Spesifikasi perijinan.

6. Insentip keuangan meliputi: 1) Insentip pajak untuk meninggalkan area yang belum berkembang, 2) Kebijakkan pinjaman untuk menghambat pembangunan.

7. Skema perencanaan tata guna lahan meliputi: Agihan aktivitas / pembangunan, termasuk pelarangan jenis aktifitas dan atau area yang berkembang (zona bahaya) termasuk seting tempat pertolongan / keselamatan.
8. Pendidikan meliputi: Komunikasi, pendidikan dan ajakan / anjuran.

9. Skema penjaminan kerugian dengan ansuransi.

Untuk mitigasi secara umum yang dapat dilakukan di daerah penelitian antara lain sebagai berikut:

a. Jangka pendek

1. Kesiagaan dan kewaspadaan masyarakat menghadapi kemungkinan terjadinya bencana alam tanah longsor. 
2. Memberitahukan secara lengkap tentang gejala awal tanah longsor.

3. Pada daerah yang termasuk zona kerentanan gerakan tanah menengah dan tinggi tidak digunakan untuk lahan pertanian yang banyak memerlukan air.

4. Memberikan penyuluhan kepada masyarakat mengenai dampak pemanfaatan lahan yang tidak tepat.

5. Menyebar luaskan informasi mengenai daerah-daerah rawan longsor, sehingga masyarakat waspada.

6. Jika terjadi bencana alam gerakan tanah/ tanah longsor perlu dilakukan langkah-langkah represif.

7. Pada daerah yang termasuk zona kerentanan gerakan tanah tinggi, sering terjadi gerakan tanah, agar dihindarkan untuk daerah pengembangan pemukiman, pada daerah tersebut disarankan untuk dijadikan daerah konservasi.

8. Menghindari penimbunan di atas lereng dan pemotongan tegak pada kaki lereng.

9. Jangan membuka areal pesawahan pada lereng yang terjal.

b. Jangka menengah.

1. Menyediakan lahan untuk relokasi pemukiman yang berada di daerah rawan bencana tanah longsor, bila daerah tersebut sudah dinyatakan tidak layak huni.

2. Memberikan penuluhan/penerangan tentang kewaspadaan dan kesiagaan dalam menghadapi terjadinya bencana alam.

3. Melakukan pemantauan terhadap gerakan tanah yang aktif terutama pada daerah yang dilalui jalur vital secara ekonomi dan jasa dan daerah padat penduduk.

4. Pada daerah longsor yang masih aktif, perlu dibuat bangunan penambat (tiang, bronjong, tembak penahan dll.).

5. Tidak membuat pemukiman pada daerah alur maupun sisi luar kelokan sungai.
6. Membuat perencanaan yang mantap untuk menanggulangi bencana alam yang disebabkan oleh faktor non alami di daerahnya.

c. Jangka panjang

1. Menghutankan kembali lahan yang gundul (kritis).

2. Dalam pengembangan wilayah perlu memasukkan parameter daerah rawan bencana alam sebagai faktor pembatas.

3. Dalam pemanfaatan lahan harus memperhatikan tata guna lahan serta memelihara/memperhatikan kelestarian alam dan lingkunan hidup di sekitarnya.

4. Perlu dihindari pembangunan perumahan pada daerah yang mempunyai kemiringan lereng $>30 \%$. Jika pembangunan terpaksa dilakukan perlu analisis kesetabilan lereng secara rinci pada setiap lokasi tapak (site Plan).

5. Memasukan wilayah rawan tanah longsor sebagai faktor pembatas dalam penyusunan RUTRK maupun RTRK yang dituangkan dalam Peraturan Daerah (Perda).

6. Melakukan pengawasan/monitoring baik lingkungan alamnya maupun aktivitas penduduknya, kaitannya dengan ancaman bencana alam gerakan tanah.

\section{KESIMPULAN DAN SARAN}

\section{Kesimpulan}

Dari uraian tersebut di atas dapat disimpulkan sebagai berikut: daerah penelitian termasuk daerah rawan longsorlahan, faktor penyebab yang dominan bila dilihat dari besrnya harkat masing-masing parameter adalah batuan, lereng, dan pelapukan batuan. Oleh karena itu mitigasi yang cocok adalah dengan usaha-usaha secara fisik yaitu perbaikan saluran drainase maupun pola penggunaan lahan. Daerah penelitian memiliki kelas risiko longsorlahan rendah 
hingga tinggi, maka untuk usaha-usaha mitigasi harus mengutamakan wilayah yang berisiko tinggi terlebih dahulu. Usaha-usaha mitigasi yang dapat dilakukan di daerah penelitian harus mengacu pada faktor penyebab yang dominan dan dapat dilakukan dengan prioritas untuk jangka pendek, janka menengah, dan jangka panjang.

\section{Saran}

Peneliti menyarankan untuk meminimalisasi risiko yang diakibatkan oleh long- sorlahan di daerah peneliti perlu dilakukan mitigasi untuk jangka pendek dengan cara sosialisasi kepada masyarakat bahwa wilayahnya termasuk daerah yang rawan longsorlahan. Oleh karena itu perlu antisipasi terhadap risiko dengan cara pelatihan mitigasi bencana longsorlahan secara periodik. Untuk jangka panjang pada daerah penelitian perlu dilakukan mitigasi dengan cara perbaikan pola aliran dan penggunaan lahan yang memperhatikan kerawanan longsorlahan.

\section{DAFTAR PUSTAKA}

Alexander, 1991. Information Technology in Real-Time for Monitoring and Managing Natural Disasters, Progress in Physical Geography; Volume 15; Number 3; pp. 238 - 260.

Bemmelen, R.W., Van, 1949. The Geology of Indonesia, Vol IA, . Government Printing Office, The Hague.

Dibyosaputro, 1998. Longsorlahan di daerah Kecamatan Samigaluh Kabupaten Kulonprogo Daerah Istimewa Yogyakarta, Laporan Penelitian, Lembaga Penelitian UGM, Yogyakarta.

Dooley, 1996. Panduan Pelatian Analisis dan Pengeloloaan Risiko. Terjemahan, oleh: Roma Chrysta Manurung, Pusat studi Lingkungan Hidup- ITB.

Montz, 1993. Hazard Area Disclosure in New Zealand: The Impacts on Residential Property Values in Two Communities, Applied Geography and Development; Volume 13, Institute for Scientific Co-operation, Tubingen.

Mardiatno, 2001. Risiko Longsor di Kecamatan Girimulyo Kabupaten Kulonprogo Daerah Istimewa Yogyakarta, Tesis S2, Program Pascasarjana Universitas Gadjah Mada, Yogyakarta.

Melching, 1999. Comprehensive Risk Assessment for Natural Hazards, World Meteorological Organization.

Pannekoek, 1949, Garis Besar Geomorfologi Pulau Jawa. Terjemahan, oleh Budio Basri, Jakarta.

Pemerintah Kabupaten Banyumas, 2003. Pemetaan Daerah Rawan Bencana Gerakan Tanah Di Kecamatan Lumbir, Laporan Akhir.

Sutikno, 1985. Dampak Bencana Alam terhadap Lingkungan Fisik. Lembaga Penelitian Pusat Penelitian Lingkungan Hidup UGM Yogyakarta dan Kantor Menteri Negara $\mathrm{KLH}$. 
Suwarno, 2004. Pemetaan Bahaya Longsorlahan Di Kecamatan Gumelar Kabupaten Banyumas Provinsi Jawa Tengah. Laporan Penelitian LPPM UMP.

Suwarno, 2005. Teknik Landscape Ecological Risk Information System untuk analisis risiko Longsorlahan Di Kecamatan Gumelar Kabupaten Banyumas Provinsi Jawa Tengah. Laporan Penelitian LPPM UMP.

Thornbury, W.D., 1954. Principles of Geomorphology. John Wiley and Sons Inc, New York.

Suprodjo, dan Dibyosaputro, 1991, Klasifikasi dan Evaluasi Medan, Kursus Evaluasi Sumberdaya Lahan, Fakultas Geografi UGM, Yogyakarta.

Sutikno, 2003. Mitigasi Tanah longsor, makalah diskusi, Dinas pengairan Kabupaten Banyumas. 
Lampiran 1. 